\title{
GENERATION Y AND GENERATION Z EMPLOYMENT EXPECTATIONS: A GENERATIONAL COHORT COMPARATIVE STUDY FROM TWO COUNTRIES
}

\author{
Dana Egerová1, Lenka Komárková2, Jiří Kutlák
}

\footnotetext{
1 University of West Bohemia, Faculty of Economics, Department of Business Administration and Management, Czech Republic, ORCID: 0000-0003-1824-9288, egerova@kpm.zcu.cz;

2 Prague University of Economics and Business, Faculty of Management, Department of Exact Methods, Czech Republic, ORCID: 0000-0003-1972-9558, lenka.komarkova@vse.cz;

3 University of West Bohemia, Faculty of Economics, Department of Business Administration and Management, Czech Republic, ORCID: 0000-0002-6866-6525, kutlak@kpm.zcu.cz.
}

\begin{abstract}
Generational differences in work values and workplace expectations have become a widely discussed research and intervention topic in recent years. However, little is known about Generation Z, who are now entering the labour market, and this presents challenges to both researchers and companies. Therefore, the primary purpose of the present study is to extend generation research by examining generational cohort differences in workplace expectations, specifically between Generation Z and the previous closest generation, Generation Y. The study is also intended to add to the limited empirical evidence of the workplace expectations of the most recent Generation Z. The theoretical framework guiding this study includes generational cohort theory and anticipatory psychological contract dimensions: job content, career development, social atmosphere, the fairness of organisational policies and rewards. The study was based on an online questionnaire survey. Data was collected from a sample of 1,000 respondents for the Czech Republic and 600 for the Slovak Republic including Generations $Y$ and $Z$ in the ratio 1:1. The generational differences in the workplace expectations, controlling the effects of gender and country, were investigated using multiple linear regression. The overall findings of the study indicate that both generations are more similar than different regarding their future employment expectations. We also find that those preferences may be more heterogeneous within a homogeneous group than across generational cohorts. The findings specifically indicate that some characteristics, such as geographical environment, professional experience and gender may shape employment expectations more than generational difference. The study suggests that companies also need to appreciate heterogeneity within a homogeneous generational group instead of treating current or prospective potential employees simply as members of one generation. The directions of future research, as well as the limitations of the study, are discussed.
\end{abstract}

Keywords: Employment expectations, anticipatory psychological contract, generational differences, Generation Y, Generation Z.

JEL Classification: M1, M5, J1.

APA Style Citation: Egerová, D., Komárková, L., \& Kutlák, J. (2021). Generation Y and Generation Z Employment Expectations: A Generational Cohort Comparative Study from Two Countries. E\&M Economics and Management, 24(3), 93-109. https://doi.org/10.15240/ tul/001/2021-03-006 


\section{Introduction}

Generational differences in various workrelated characteristics such as work values, motivational drivers, preferences and workplace expectations have become a widely discussed research and intervention topic in recent years (Lyons \& Kuron, 2014; Campbell et al., 2015; Sobrino-De Toro et al., 2019). The growing interest reflects the impact of the demographic, economic and technological shifts in society on the world of work and on how organisations maintain a multigenerational workforce (Lub et al., 2016). In recent years, research has primarily focused on the members of three generations (Baby Boomers, Generation X and Generation $Y$ ) to explore the features that differentiate these generations from each other in terms of workplace values, expectations, attitudes and organisational outcomes (Moore et al., 2015). At present, the next generation of employees - Generation Z - is about to enter the labour market, which will present challenges and opportunities for both researchers and companies (Knapp et al., 2017; Rodriguez et al., 2019). The understanding of the workplace characteristics of the members of the new generation is required to develop and adopt effective recruitment and retention strategies and practices for these new employees (De Vos et al., 2009; Lanier, 2017; Tang, 2019).

Previous studies focused on generational differences in the work values and workplace expectations between Baby Boomers, Generation $X$ and Generation $Y$ have indicated that generational differences actually exist (Lyons \& Kuron, 2014; Lub et al., 2016; Šimsová \& Reissová, 2016). These studies also show that understanding generational differences has the potential to improve how companies treat a multigenerational workforce. Conversely, several studies (Lester et al., 2012; Mencl \& Lester, 2014) examining generational differences found more similarities between the generations than differences. The mixed findings call for more inquiry into generation differences and similarities, especially those related to employment expectations.

Moreover, there is an increasingly prevalent perception among scholars that Generation $Z$ shares many characteristics with the previous closest generation, Generation Y (Maloni et al., 2019). According to Lanier (2017), Generation Z represents a continuation and extension of Generation Y workplace demands.
At the same time, due to different events and circumstances, Generation $Z$ have shown that they are considerably different from Generation Y (Schroth, 2019; Tang, 2019). Following on from this, we assume that different generation characteristics would also be reflected in the different pre-employment expectations that the members of Generation $Y$ and Generation $Z$ have about their future employment. Thus, the question arises as to what extent the generational differences and similarities exist between these two generations regarding their employment expectations. As various authors (Costanza \& Finkelstein, 2015; Maloni et al., 2019) have stated, the empirical evidence and the theoretical justification for generation differences is lacking, especially when related to employment expectations between Generation $Z$ and the previous generations.

Subsequently, pre-employment expectations are formed by individuals before entering formal employment and constitute the basis for the perceived obligations of the anticipatory psychological contract - APC (Sutton \& Griffin, 2004). The APC is defined as individuals' preemployment beliefs of what they expect to occur in the future employment relationship. The research has shown that APC mediates the relationship between organisational characteristics and decisions about job choice. Furthermore, the APC provides a more concrete outlook on future employee expectations in relation to their future work. Thus, in line with authors such as Lub et al. (2016), we argue that the APC proves to be a useful and relevant theoretical concept to explore the expectations of prospective employees.

The study aims to answer the question of whether there are differences and similarities in workplace expectations depending on the generational group, specifically between Generation Z and Generation Y. The paper responds to the lack of generational cohort comparative studies with Generation Z in this field. Moreover, the issue is addressed in the context of two countries. The theoretical framework guiding this study includes the APC with a content-based approach and generational cohort theory.

The study contributes to the literature on generations through examining the generational differences and similarities concerning workplace expectations by comparing Generation $Y$ and Generation Z. The study contributes to the 
literature on the APC by applying the contentbased approach, which distinguishes five dimensions: job content, career development, social atmosphere, organisational policies and rewards (Freese et al., 2011; Lub et al., 2016). Finally, the study provides useful information for managers and HR professionals to design and develop effective recruitment and retention strategies and policies for different generational cohorts.

The paper is organised as follows. In the first section, theoretical background, the generational cohort theory and the APC to develop research hypotheses are reviewed. Next, the methods used to test the hypotheses and the research instrument are explained and then the study results are reported and discussed. Finally, the conclusions and limitations of the study are provided.

\section{Theoretical Background \\ 1.1 Generational Cohort Theory}

Academic research on generation differences in the workplace has demonstrated that various characteristics vary across generations. The majority of studies concerning generational differences in work-related variables such as work values, attitudes, motivation, leadership etc, have adopted the generational cohort theory (Jones et al., 2018). This theory is intended to identify the profile and common characteristics of different generations and thus provide a deeper understanding and insight into age-related issues in contemporary organisations (Goh \& Lee, 2018). Brosdahl and Carpenter (2011) argue that the theory provides a useful segmentation of generations by age, according to which, every generation cohort differs from the others in some way because they have experienced different events occurring at different times (Ignatius \& Hechanova, 2014). As Smola and Sutton (2002) stated, belonging to the same generational cohort enables to distinguish one cohort from another. Furthermore, each generational cohort shares memories as a result of the age group, important life events and major changes in society (Lim \& Parker, 2020). This theory postulates that generational differences are not determined by an individual's age but rather by the shared influences and experiences of a particular generation (Jones et al., 2018). As a result, it is argued that generational changes are primarily a function of social events rather than biological processes.

A generational cohort can be defined as a group of individuals who were born around the same time and who experienced the same or similar events during their formative years (Noble \& Schewe, 2003). As stated (Twenge et al., 2011), the members of each generational cohort reflect important historical events, social changes in society occurring within the same period and the values emphasised during the particular periods. This determines the specific experience of each generation (Parry \& Urwin, 2011). Therefore, different generations share experiences that differentiate one generation from another (Noble \& Schewe, 2003). Moreover, it is postulated that these groups' experiences, events and changes influence the values, attitudes, and beliefs of the members of each generation and set them apart from each other (Brosdahi \& Carpenter, 2011). Other authors (Schewe \& Meredith, 2004; Dou \& Li, 2013) further state that various personal values remain relatively stable during the generation's lifetime. Different influences are also likely to be manifested in the behavioural differences of each generation (Lyons \& Kuron, 2014). Thus, individuals growing up in the same period may think and act similarly as a result of the influence of generations sharing collective memories (Carpenter, 2012).

Viewing generations from the cohort perspective enables to describe a generational cohort as a more homogenous group with observed characteristics, concrete boundaries and time frame. The term generational cohort is synonymous with the term generation in this study.

\subsection{Generation Taxonomy}

A vast amount of different data can be encountered when classifying individual generations according to the annual definition. This data differs in part and is partly identical. The most agreement can be found in the older generations, such as the Baby Boomers and Generation X. Their definition is largely influenced by historical events in the form of World War II, which affected global events and subsequently generations around the world. The large majority of authors (e.g., Tapscott, 2009; Lancaster \& Stillman, 2010; Bejtkovský, 2016) thus agree on the classification of the Baby Boomer generation for people born 
during 1946-1964. There is also agreement in the definition of Generation X, who were born between 1965 and 1982 (Werth \& Werth, 2011).

However, the annual classification of the younger generations, i.e., the examined Generation $Y$ and Generation $Z$, is already different. Although the members of these generations are described as global due to the development of information and communication technologies, there is no great consensus among the authors. The reason for this may be, for example, that since the end of World War II, the world has not encountered any cultural or historical event that would affect the whole world. Social and technological events are often used to define individual generations. Examples include the commercialisation of the internet and the emergence of the World Wide Web, which began in the early 1990s. In domestic conditions, there was a greater development around 1994, when many commercial internet connection providers entered the market (Eger \& Egerová, 2013). Other authors (Howe \& Straus, 2000; Glass, 2007; Eger et al., 2018) are also inclined to this date when anchoring Generation $Y$ and can thus be defined as between 19831994. This is followed by Generation Z with an annual anchorage of 1995-2010 (Bencsik et al., 2016; Issa \& Isaias, 2016). For our study, Generation $Y$ is defined between 1983-1994 and Generation Z between 1995-2010 (Bencsik et al., 2016; Issa \& Isaias, 2016).

\subsection{Anticipatory Psychological Contract}

A growing body of research shows that the psychological contract is an important antecedent of employee outcomes. According to De Vos et al. (2009), the psychological contract processes gradually from the preemployment stage and throughout the different stages of employment. Therefore, it is important to have an insight into the psychological contract of the current employees as well as from the future employee's viewpoint, i.e., the anticipatory psychological contract. The anticipatory psychological contract is defined as an individuals' subjective expectations about their future employment (De Vos et al., 2009).

Ruchika and Prasad (2019) assume that the APC is formed in the period before entering an organisation during which the future employees develop expectations about future employment relationships. Similarly, the authors Greese et al. (2013) claim that before entering the organisation the prospective employees already develop a mental schema that affects their expectations and thus determines their choice of future employer. As stated by De Hauw and De Vos (2010), the APC is the lens through which prospective employees view their future employer. Ruchika and Prasad (2019) confirm that the APC plays a vital role in the final decision on choosing a particular employer.

On the other hand, it should be mentioned that a job seeker's APC is highly subjective and formed based on incomplete and limited information (Ruchika \& Prasad, 2019). Nevertheless, in line with the previous authors, we argue that the APC presents a valuable framework to investigate generational differences in the job seekers' beliefs and expectations about potential employment relationships.

Research of the psychological contract in the employment context has largely been conducted in relation to the types of psychological contract, e.g., transactional vs. relational (Fernandes et al., 2016). Lub et al. (2012) argue that the contract type approach examines the nature of the contract, although they do not specify the content of the contract. Therefore, according to these authors, to investigate the psychological contract, specifically the APC, from the content-based approach may provide a better understanding of generational expectations.

The content-based approach views the APC as a multidimensional concept distinguishing different dimensions. From the point of employee expectations, Lub et al. (2016) distinguish five dimensions of the APC: job content, career development, social atmosphere, the fairness of organisational policies and rewards. De Vos et al. (2009) propose another five dimensions of employee expectations: interesting job content, career opportunities, social atmosphere and work-life balance, and financial. Gresse et al. (2013) proposed a structural anticipatory psychological model involving normative and individual expectations. The individual expectations include an attractive salary, benefits, employee assistance, personal skill development opportunities, status in the workplace and mobility opportunity. The normative expectations include a reasonable salary, necessity benefits, reasonable 
conditions of employment and environment, employee development and well-being, jobrelated skills development, and respect in the workplace. Our study is based on the Lub et al. (2016) concept.

\section{Job Content}

The area of job content, which can include the meaningfulness of the work performed and the interest or diversity of activities, is one of the key areas for Generation $Z$ with regard to the expectations from their professional lives. A meaningful job, together with reward and professional development, is one of the most important motivating factors in the workplace (Bencsik et al., 2016; Kubátová, 2016). The importance of this area for Generation Z can also be confirmed in relation to the outside world. Members of the youngest economically active generation are not indifferent to the surrounding world and expect companies where they work or will work to be positive about the socio-environmental environment of the company (Deloitte, 2018). Some authors (Sobrino-DeToro et al., 2019; Zúñiga et al., 2019) state that more than half of Generation $Z$ would like to change the world for the better through their professional career. In contrast to their predecessors, Wiedmer (2015) also confirms the greater emphasis on job content factors in Generation Z. Therefore, we hypothesise:

H1: The pre-employment expectations related to job content are more important for Generation Z than for Generation Y.

\section{Career Development}

The area of career development can be considered to be more or less the same for both generations. According to the ManpowerGroup (2016) study, members of Generation Y expect to have a longer working life in their professions than previous generations while they are reconciled with the fact that their retirement will be up to the age of 70 or may even have no limit. For their career expectations, they state that, unlike their predecessors who climb the so-called career ladders, Generation $Y$ will work more in so-called 'career waves' that can be represented by job changes, volunteering or other activities (ManpowerGroup, 2016). The most frequently mentioned reason to change jobs is to acquire new skills or qualifications. Members of Generation Z also have very similar expectations from their career. Generation $Z$ does not recognize the traditional career ladder system and the system of work positions in companies (Rood, 2011; Baldonado, 2018). Like Generation Y, they combine career change with the acquisition of new skills and opportunities to work on their own projects, rather than traditional career advancement (Deloitte, 2018). However, many authors agree that career advancement or change is one of the main motivators for both generations (Fratričová \& Kirchmayer, 2018; Bencsik et al., 2016). Therefore, we hypothesise:

H2: The pre-employment expectations related to career development are similarly important for both generations.

\section{Organisational Policies}

The organisational policies area can be defined as the policies or procedures that organisations apply to their employees. This can include, for example, methods of communication and supervision, feedback, fair treatment or the regulations of the organisation and the treatment of company values (Lub et al., 2016). An area frequently mentioned concerning Generation $Z$ is the issue of diversity in the workplace. For members of Generation Z, diversity is a crucial topic and it can be said that they expect it as a matter of course for companies rather than as an element by which they make decisions. High expectations from organisational policies are evident in Generation Z concerning the impact on the socio-environmental environment and the values of the organisation (see job content above). Regarding the issue of feedback, then unlike the Millennials, Generation Z require higher frequency and consistency (Puiu, 2017). For Generation Y, the need for so-called 'from demand' feedback can be indicated. With the arrival of Generation $Y$ on the labour market, increasing demands for flexible work and worklife balance can be observed. For Generation Z, these requirements are beginning to be taken for granted (Meret et al., 2018). This is due to the strong positive attitude from Generation $Z$ toward technologies and often blurs the differences between work and leisure. The members of this generation are increasingly eager for the opportunity to work through remote access at any time and from anywhere, regardless of working hours. Therefore, we hypothesise that: 
H3: The pre-employment expectations related to organisational policies are more important to Generation Z than Generation Y.

\section{Social Atmosphere}

The area of social atmosphere in the workplace, represented, for example, by communication in the workplace, workplace culture and workplace organisation, is a very important topic for both the selected generations although, in connection with Generation Z, this importance is escalating. On the contrary, according to Lub et al. (2016), a lower level of expectations can be observed for Generation $Y$ in relation to the issue of the social atmosphere. According to studies (Bencsik et al., 2016; Miller, 2018), the work environment and atmosphere are a key theme and motivator for Generation Z. Fratričová and Kirchmayer (2018) state in their research that Generation $Z$ also explicitly mention collaborators. This is also confirmed by Puiu (2017). According to Cseh-Papp et al. (2015), a cheerful team is the second most important factor when choosing a job. The difference between the examined generations is also evident in their expectations from the work environment. Generation Z tends toward a private environment and thus there is a clear deflection from shared offices and spaces, which were characteristic of the Millennials (Puiu, 2017). As far as communication is concerned, despite the strong influence of social media, a positive attitude of Generation $Z$ to personal communication can be observed, which is confirmed in research by Kutlák (2019) and Bejtkovský (2016). Hence, we hypothesise:

H4: The pre-employment expectations related to social atmosphere are more important for Generation Z than for Generation Y.

\section{Rewards}

The issue of rewards can be described as relatively stable across all generations in the long term. As such, wages are one of the most important motivating factors for most members of all the generations. Differences can be noted upon deeper examination, where for older generations (Baby Boomers, $\mathrm{X}$ ), wages or remuneration serve primarily to provide for the family and family background (Kutlák, 2018). For the younger generations, for whom wages are still among the most important factors, they are a means to meet needs and desires (Cseh-Papp et al., 2015; Bencsik et al., 2016). As reported by Lub et al. (2016), many studies differ in examining Generation $Y$ regarding the issue of rewards. However, due to the economic crisis in 2008, the importance of wages for the members of this generation is growing. According to the ManpowerGroup study (2016), as many as $92 \%$ of the Millennials surveyed prioritise wages and remuneration when looking for a new job. A similarly high level of importance is also confirmed for the younger Generation Z (Bencsik et al., 2016; Kubátová, 2016; Puiu, 2017). Hence, we hypothesise that:

H5: The pre-employment expectations for rewards are similarly important to both generations.

\section{Data and Methods}

For our research, we understand preemployment expectations in a broader sense, including expectations for future employment in the case of people already employed. In addition, for ethical reasons, in the case of the younger Generation Z, only adult respondents over the age of 18 participated in the empirical study. The study focused on the APC was based on an online questionnaire survey and was conducted in two countries with a common history, namely the Czech Republic (CZ) and the Slovak Republic (SK), in autumn 2019.

The primary data were collected using an online panel administered by The Talk Group. The use of online panels in surveys is growing as they make it possible to efficiently obtain sufficiently large samples with a diverse structure of respondents (Hays et al., 2015). Specifically, Talk Online Panel (2019) consists of approximately 1.3 million potential respondents from 25 European countries, including 60 thousand Czechs and 28 thousand Slovaks. Research samples of Czech and Slovak respondents were taken based on quota sampling (e.g., Ochoa \& Porcar, 2018). This sample selection method ensures a predetermined distribution of respondents according to their basic demographic characteristics such as gender and age. The quality of collected data was guaranteed by the fact that the Talk Group is a member of ESOMAR and follows its guidelines (Talk Online Panel, 2019). The used online panel could be considered as representative because almost all people from Generations $Y$ and $Z$ are internet users (Eurostat, 2020). 
The sample size chosen was 1,000 respondents for $\mathrm{CZ}$ and 600 for SK, taking into account the size of the population. Note that the Public Opinion Research Centre (CVVM, 2019) also usually uses a sample size of 1,000 respondents obtained on the basis of quota sampling in the Czech population surveys. The research samples in both countries included Generations $Y$ and $Z$ in the ratio 1:1. Each generation was thus represented by a total of 800 respondents (CZ: 500 , SK: 300 ) with the same number of men and women to avoid gender imbalances in the sample. There was also an effort to include respondents with different job experience and from various regions in both samples. Tab. 1 shows the distribution of respondents in each country regarding generation, gender and job experience. In the case of job experience, three categories were distinguished (None - no experience; Partial partial experience in the form of a brigade, parttime or freelance work; Full - full experience as a full-time employee). Most respondents from Generation $Y$ belong to the third category with full experience (CZ: $90.4 \%$, SK: $87.7 \%$ ), while most respondents from Generation $Z$ belong to the second category with partial experience (CZ: $67.2 \%$, SK: $62.7 \%$ ). This is in line with the fact that members of Generation $Z$ are gradually entering the labour market.

In addition to the basic demographic and socio-economic questions about the

Tab. 1: Distribution of respondents by country (CZ, SK), generation (Y, Z), gender (M, F), and job experience (None, Partial, Full)

\begin{tabular}{|c|c|c|c|c|c|c|c|c|c|c|c|c|}
\hline \multirow{3}{*}{$\begin{array}{l} \\
\text { Job } \\
\text { experience }\end{array}$} & \multicolumn{6}{|c|}{ Czech Republic (CZ) } & \multicolumn{6}{|c|}{ Slovak Republic (SK) } \\
\hline & \multicolumn{3}{|c|}{ Gen $Y$} & \multicolumn{3}{|c|}{ Gen Z } & \multicolumn{3}{|c|}{ Gen Y } & \multicolumn{3}{|c|}{ Gen Z } \\
\hline & M & $\mathrm{F}$ & Total & M & $\mathrm{F}$ & Total & M & $\mathrm{F}$ & Total & M & $\mathrm{F}$ & Total \\
\hline None & 3 & 3 & 6 & 21 & 26 & 47 & 1 & 1 & 2 & 14 & 11 & 25 \\
\hline Partial & 24 & 18 & 42 & 152 & 184 & 336 & 7 & 28 & 35 & 90 & 98 & 188 \\
\hline Full & 223 & 229 & 452 & 77 & 40 & 117 & 142 & 121 & 263 & 46 & 41 & 87 \\
\hline Total & 250 & 250 & 500 & 250 & 250 & 500 & 150 & 150 & 300 & 150 & 150 & 300 \\
\hline
\end{tabular}

Source: own

respondents, the questionnaire primarily examined the level of their expectations in the individual dimensions of APC (job content, career development, organisational policies, social atmosphere, rewards). Each of the five dimensions was represented in the questionnaire by six items (e.g., "I want to have the opportunity to do a job that makes sense" for job content, "I want to have a career growth opportunity" for career development, "I want the employer to treat employees fairly and with respect" for organisational policies, "I want the atmosphere in the workplace to be friendly" for social atmosphere, and "I want to receive a reward for above-standard performance/work" for rewards). It is important to note that the items were derived and modified from the studies of Freese et al. (2011), Gresse et al. (2013) and Lub et al. (2016). All thirty items were evaluated using the Likert five-level scale (1 - completely unimportant; 2 - quite unimportant; 3 - neither important nor unimportant; 4 - quite important; 5 - completely important). The various scales of answers are used in psychological contract research; however, a five-point scale is applied relatively often (Freese \& Schalk, 2008). The variables representing these dimensions were calculated as an average over the relevant six items.

One-word dimension names were chosen to present the results in tables and figures (content instead of job content, career instead of career development, policies instead of organisational policies, atmosphere instead of social atmosphere, and rewards). Furthermore, Tab. 2 gives values of Cronbach's $\alpha$ for each of the five considered dimensions for individual countries (CZ, SK) and together. The values between 0.76 and 0.85 demonstrate acceptable or good internal consistency of the items used. 

Tab. 2: Calculated Cronbach's $\alpha$ (with related 95\% confidence interval)
for the considered APC dimensions

\begin{tabular}{l|l|c|c|c}
\multicolumn{1}{c|}{ Dimension } & \multicolumn{1}{c|}{ Shortcut } & CZ & SK & Total \\
\hline Job content & Content & $0.76(0.74 ; 0.79)$ & $0.78(0.76 ; 0.81)$ & $0.77(0.75 ; 0.79)$ \\
\hline $\begin{array}{l}\text { Career } \\
\text { development }\end{array}$ & Career & $0.78(0.76 ; 0.80)$ & $0.84(0.82 ; 0.86)$ & $0.81(0.79 ; 0.82)$ \\
\hline $\begin{array}{l}\text { Organisational } \\
\text { policies }\end{array}$ & Policies & $0.84(0.83 ; 0.86)$ & $0.84(0.82 ; 0.86)$ & $0.84(0.83 ; 0.85)$ \\
\hline $\begin{array}{l}\text { Social } \\
\text { atmosphere }\end{array}$ & Atmosphere & $0.79(0.77 ; 0.81)$ & $0.81(0.79 ; 0.84)$ & $0.80(0.78 ; 0.82)$ \\
\hline Rewards & Rewards & $0.83(0.82 ; 0.85)$ & $0.85(0.83 ; 0.87)$ & $0.84(0.83 ; 0.84)$ \\
\hline
\end{tabular}

Source: own

The three research hypotheses $\mathrm{H} 1$ (for job content), $H 3$ (for organisational policies), and $\mathrm{H} 4$ (for social atmosphere) supposing a generational difference have the form of the alternative statistical hypothesis, while the other two $H 2$ (for career development) and $\mathrm{H} 5$ (for rewards) supposing a similarity between the Generations $Z$ and $Y$ have the form of the null statistical hypothesis. First, the data obtained from the questionnaire was processed using descriptive statistics. The data file did not contain missing values. Second, the research hypotheses were investigated based on multiple linear regression where gender and country were included in the model as control variables. Regression model and gender as a control variable were also used in the onecountry studies of De Hauw and De Vos (2010) or De Vos et al. (2019). The statistical analysis was processed in the R software (R Core Team, 2020), version 3.6.3. For statistical hypothesis testing, a standard significance level of $5 \%$ was used.

\section{Results}

Tab. 3 presents descriptive statistics in the form of sample means and standard deviations for each generation with gender differentiation for the Czech sample (1,000 respondents). Tab. 4 then presents the same data for the Slovak sample (600 respondents). Fig. 1 shows the average values of the dimensions obtained using spider (radar) graphs with the resolution of the Generations $Y$ and $Z$ and separately for each country. The scale of the graph was adjusted for better visibility of the differences. The data presented shows that respondents from both generations have the highest preemployment expectations concerning rewards and, conversely, the lowest concerning career. Generational differences in their expectations are on average slight. The largest absolute difference in Fig. 1 was recorded among Czechs in the social atmosphere $(0.12)$.

Tab. 3: Czech sample means (standard deviations) for the APC dimensions
by generation and gender

\begin{tabular}{l|c|c|c|c|c|c}
\multicolumn{1}{c|}{ CZ } & \multicolumn{3}{|c|}{ Gen Y } & \multicolumn{3}{c}{ Gen Z } \\
\hline \multicolumn{1}{c|}{ Dimension } & Male & Female & Total & Male & Female & Total \\
\hline Content & $3.89(0.64)$ & $3.93(0.61)$ & $3.91(0.63)$ & $3.81(0.65)$ & $3.84(0.62)$ & $3.82(0.64)$ \\
\hline Career & $3.78(0.65)$ & $3.75(0.64)$ & $3.77(0.65)$ & $3.81(0.65)$ & $3.79(0.72)$ & $3.80(0.69)$ \\
\hline Policies & $4.14(0.68)$ & $4.22(0.60)$ & $4.18(0.64)$ & $3.99(0.62)$ & $4.21(0.63)$ & $4.10(0.64)$ \\
\hline Atmosphere & $4.03(0.62)$ & $4.11(0.59)$ & $4.07(0.61)$ & $3.87(0.63)$ & $4.03(0.66)$ & $3.95(0.65)$ \\
\hline Rewards & $4.26(0.60)$ & $4.40(0.61)$ & $4.33(0.61)$ & $4.22(0.65)$ & $4.26(0.66)$ & $4.24(0.66)$ \\
\hline
\end{tabular}




\section{Tab. 4: Slovak sample means (standard deviations) for the APC dimensions by generation and gender}

\begin{tabular}{l|c|c|c|c|c|c}
\multicolumn{1}{c|}{ SK } & \multicolumn{3}{|c|}{ Gen Y } & \multicolumn{3}{c}{ Gen Z } \\
\hline \multicolumn{1}{c}{ Dimension } & Male & Female & Total & Male & Female & Total \\
\hline Content & $3.84(0.68)$ & $4.00(0.62)$ & $3.92(0.66)$ & $3.85(0.67)$ & $4.00(0.57)$ & $3.92(0.62)$ \\
\hline Career & $3.83(0.69)$ & $3.86(0.70)$ & $3.84(0.69)$ & $3.87(0.73)$ & $3.94(0.67)$ & $3.91(0.70)$ \\
\hline Policies & $4.14(0.58)$ & $4.24(0.58)$ & $4.19(0.58)$ & $4.10(0.71)$ & $4.24(0.53)$ & $4.17(0.63)$ \\
\hline Atmosphere & $4.03(0.67)$ & $4.14(0.62)$ & $4.09(0.65)$ & $3.98(0.72)$ & $4.17(0.50)$ & $4.07(0.62)$ \\
\hline Rewards & $4.27(0.63)$ & $4.38(0.66)$ & $4.32(0.65)$ & $4.34(0.62)$ & $4.38(0.56)$ & $4.36(0.59)$ \\
\hline
\end{tabular}

Source: own

\section{Fig. 1: Spider graphs of Czech and Slovak sample means for the APC dimensions with generational resolution}

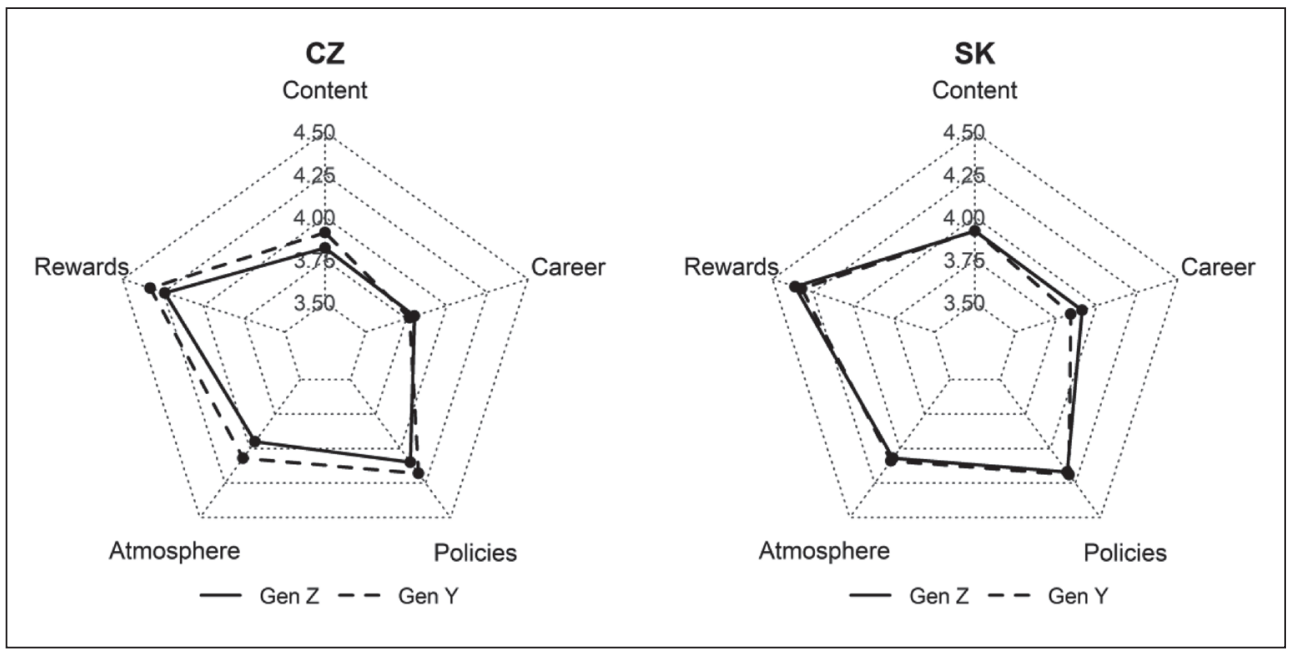

The multiple regression model was used to assess the dependencies of the individual APC dimensions on dichotomous explanatory variables, namely on generation (Gen $\mathrm{Y}-0$, Gen $Z-1)$, country $(C Z-0$, SK -1$)$, and gender (Male - 0, Female - 1). Specifically, we constructed five linear models with respect to the five APC dimensions as dependent variables. First, we considered more complex models with two-way interactions although these were insignificant in the total (content: $p=0.135$; career: $p=0.707$; policies: $p=0.260$; atmosphere: $p=0.248$; reward: $p=0.155$ ). Therefore, we used the model only with the main effects without interactions for each APC dimension.

The basic results of the multiple regression (five models) are presented in Tab. 5, including $p$-values indicating the significance of the effects. In addition, there are estimates of the differences in APC dimension means between the categories according to the three explanatory dichotomous variables (generation, country, gender) and the related standard errors for such estimates. Seven statistically significant results at the usual significance level of $5 \%$ can be observed and are highlighted by the grey background. 
Estimates, standard errors (SE) and related t-test $p$-values for differences Tab. 5: in means of APC dimensions between the categories by explanatory variables (generation, country, and gender) within the regression models used

\begin{tabular}{l|c|c|c|c|c|c|c|c|c} 
Difference & \multicolumn{3}{|c|}{ Gen Z-Gen Y } & \multicolumn{3}{c|}{ SK - CZ } & \multicolumn{3}{c}{ Female - Male } \\
\hline Dimension & Estimate & SE & P-value & Estimate & SE & P-value & Estimate & SE & P-value \\
\hline Content & -0.05 & 0.03 & 0.119 & 0.05 & 0.03 & 0.093 & 0.08 & 0.03 & 0.012 \\
\hline Career & 0.05 & 0.03 & 0.164 & 0.09 & 0.04 & 0.010 & 0.01 & 0.03 & 0.868 \\
\hline Policies & -0.06 & 0.03 & 0.074 & 0.04 & 0.03 & 0.218 & 0.14 & 0.03 & $<0.001$ \\
\hline Atmosphere & -0.08 & 0.03 & 0.012 & 0.07 & 0.03 & 0.033 & 0.13 & 0.03 & $<0.001$ \\
\hline Rewards & -0.04 & 0.03 & 0.192 & 0.06 & 0.03 & 0.086 & 0.08 & 0.03 & 0.007 \\
\hline
\end{tabular}

Concerning the research hypotheses (see Tab. 6), we expected three statistically significant results in the case of generational differences, namely for job content $(H 1)$, organisational policies $(H 3)$, and social atmosphere $(H 4)$. The results in Tab. 5 demonstrated only one in the case of social atmosphere $(p=0.012)$. Therefore, we cannot confirm $\mathrm{H} 1$ and $\mathrm{H} 3$. Focusing on the social atmosphere in more detail (Estimate: -0.08 ), it can be observed that after adjustment for the influence of the other considered variables, country and gender (the ceteris paribus principle), Generation $Y$ considers this dimension more important than Generation Z. This finding is in direct contradiction to $\mathrm{H} 4$. To summarise, our data does not support either $\mathrm{H} 1, \mathrm{H} 3$, or $\mathrm{H} 4$; related one-sided p-values, which are more appropriate for evaluating such hypotheses, are 0.940, 0.963 , or 0.994 , respectively (Tab. 6). On the other hand, statistically insignificant results for career development (two-sided $p=0.164$ ) and rewards (two-sided $p=0.192$ ) are in accordance with $\mathrm{H} 2$ and $\mathrm{H} 5$.

Furthermore, the difference in results between the countries is detected for the dimensions of career development (Estimate: $0.09 ; \mathrm{p}=0.010$ ) and social atmosphere (Estimate: $0.07 ; p=0.033$ ). In both cases, the Slovaks rated them higher, ceteris paribus, than the Czechs. The relationship between the APC dimension variable and gender is statistically significant in four out of five cases. The only exception is career development, with no statistical difference between women and men. In other cases, women have higher pre-employment expectations than men, see estimates ranging from 0.08 to 0.14 in Tab. 5 .

To summarise, the pre-employment expectations between the $Z$ and $Y$ generations appear to be similar (in four of the five dimensions). Based on our data, it does not appear that Generation Z places more emphasis on job content, organisational policies

\section{Tab. 6: Summary and evaluation of the research hypotheses with regard to their statistical hypothesis type}

\begin{tabular}{l|c|c|c|c|c|c|c}
\multirow{2}{*}{ Dimension } & \multicolumn{3}{|c|}{ Research hypothesis } & \multicolumn{2}{c|}{ Hypothesis test } & \multicolumn{2}{c}{ Conclusion } \\
\cline { 2 - 8 } & Symbol & Z vs. Y & Statistical & Type & P-value & Statistical & Accordance \\
\hline Content & H1 & $>$ & Alternative & One-sided & 0.940 & Not proved & No \\
\hline Caree & H2 & $=$ & Null & Two-sided & 0.164 & Not reject & Yes \\
\hline Policies & H3 & $>$ & Alternative & One-sided & 0.963 & Not proved & No \\
\hline Atmosphere & H4 & $>$ & Alternative & One-sided & 0.994 & Not proved & No \\
\hline Rewards & H5 & $=$ & Null & Two-sided & 0.192 & Not reject & Yes \\
\hline
\end{tabular}




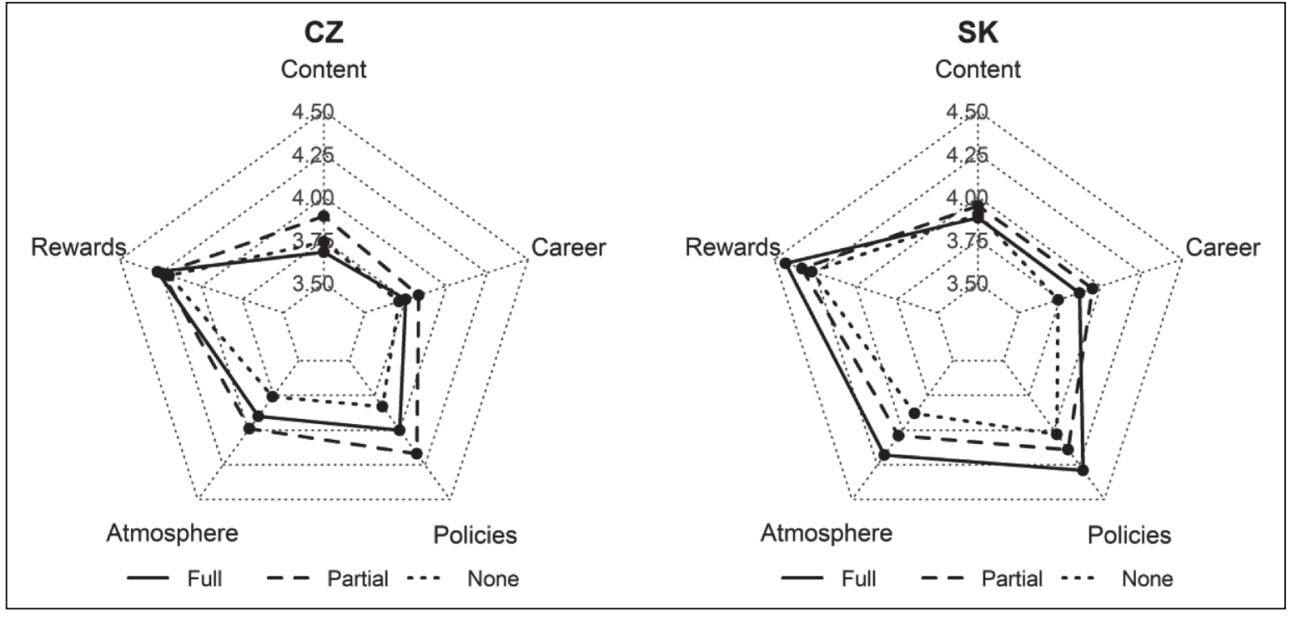

Source: own

or social atmosphere. However, it should be noted that Generation $Z$ is in the phase of entering the labour market unlike Generation $Y$, which is of working age. Therefore, in the case of Generation Z, we also focused on the relationship of APC to job experience. Fig. 2 shows the spider (radar) graphs for $\mathrm{CZ}$ and SK, where the individual categories of the job experience variable are distinguished (full, partial, none).

Furthermore, to investigate the dependence of APC (five dimensions) on job experience in Generation Z, we used five linear models, including country and gender as control effects.
Tab. 7 gives the results of the effect significance tests for job experience as a whole (ANOVA F-test) and includes the results of multiple comparisons between the categories of this effect, using the method of Hothorn et al. (2008). In other words, the presented results were adjusted for country and gender effects and the $p$-values related to pairwise comparisons were corrected for multiple testing. Statistically significant results are again highlighted by the grey background.

The results in Tab. 7 indicate that, for members of Generation Z, pre or future employment expectations related to the three

\begin{tabular}{|c|c|c|c|c|c|c|c|c|}
\hline Tab. 7: & \multicolumn{8}{|c|}{$\begin{array}{l}\text { Significance of the job experience effect on the APC dimensions in the case } \\
\text { of Generation } Z \text { (adjusted for country and gender effects) and multiple comparison } \\
\text { results (estimates and related p-values for differences in means of APC dimensions } \\
\text { between the job experience categories) within the linear models used }\end{array}$} \\
\hline \multirow{2}{*}{$\begin{array}{l}\text { Difference } \\
\text { Dimension }\end{array}$} & \multicolumn{2}{|c|}{ Job experience } & \multicolumn{2}{|c|}{ Partial - None } & \multicolumn{2}{|c|}{ Full - None } & \multicolumn{2}{|c|}{ Full - Partial } \\
\hline & F-stat & P-value & Estimate & P-value & Estimate & P-value & Estimate & P-value \\
\hline Content & 4.26 & 0.014 & 0.11 & 0.332 & -0.03 & 0.913 & -0.15 & 0.015 \\
\hline Career & 2.07 & 0.126 & 0.15 & 0.178 & 0.08 & 0.697 & -0.08 & 0.367 \\
\hline Policies & 5.40 & 0.005 & 0.26 & 0.003 & 0.24 & 0.014 & -0.02 & 0.940 \\
\hline Atmosphere & 3.82 & 0.022 & 0.20 & 0.027 & 0.23 & 0.020 & 0.03 & 0.851 \\
\hline Rewards & 1.04 & 0.355 & 0.04 & 0.851 & 0.11 & 0.429 & 0.06 & 0.434 \\
\hline
\end{tabular}


previously mentioned dimensions can change with their job experience (content: $p=0.014$; policies: $p=0.005$; and atmosphere: $p=0.022$ ). The conducted multiple comparisons then provide more detailed information. In particular, for those who have some (partial or full) job experience, their expectations are higher in the case of the organisational policies and social atmosphere dimensions compared to those without job experience. On the other hand, in the case of job content, expectations are lower for fully employed or unemployed respondents compared to those with partial job experience.

\section{Discussion and Conclusions}

The primary purpose of the study was to extend generations research by examining differences and similarities concerning workplace expectations by comparing Generation $Y$ and Generation Z. The study was also intended to add to the limited empirical evidence of the workplace expectations of Generation Z, who are entering the labour market. In addition, it was a study from two countries.

In general, the findings of the study indicate that both generations are more similar than different regarding their expectations about future employment. These findings are in line with the study of Maloni et al. (2019) who reported broad similarities between Generation $Z$ and Generation $Y$ regarding the importance of workplace expectations.

As expected, we found generational similarities for the rewards dimension. Moreover, the respondents' work expectations related to this dimension were the highest ever. The results suggest that issues such as appropriate salary, benefits, and performance-related pay should similarly be highly desirable for both generations. These findings are consistent with the research by Lyons and Kuron (2014) and Maloni et al. (2019) suggesting that financial reward, benefits and job security are important for Generation $Y$ and Generation Z. In a similar vein, support was found for the hypothesis stating that expectations related to career development, which, on the other hand, was the lowest in the respondents' expectations, are similarly important to members of both generations.

Contrary to what was hypothesised, it does not appear that Generation Z places more emphasis on the job content and organisational policies dimensions. It is assumed that meaningful and challenging work, flexible work arrangements, open communication, fair treatment of all employees, and participation opportunity appears to be a requirement for Generation $Y$ as well as Generation Z. The real surprise is that Generation $Y$ consider the social atmosphere dimensions more important than Generation Z. However, Lub et al. (2016) concluded that although Generation Y places social atmosphere relatively high in its expectations compared to other generations, concerning affective commitment and turnover intention, this dimension is insignificant.

There are several explanations for our findings. First, many studies (Dencker et al., 2008; Guillot-Soulez \& Soulez, 2014; Eger et al., 2018) exploring generational differences point out that preferences may be more heterogeneous within a homogeneous group than across cohort. This study shows that professional experience influences pre- or future employment expectations of Generation $Z$ related to the three dimensions of job content, organisational policies and social atmosphere. These findings are consistent with De Vos et al.'s (2009) statement that the psychological contract can vary from the pre-employment phase to the during-employment phase. Our study specifically revealed that individuals from Generation Z who have some (partial or full) job experience have higher expectations in the case of the organisational policies and social atmosphere dimensions compared to those without job experience. Second, the study reveals that the expectations of both generations were significantly different according to gender in four out of the five APC dimensions. The only exception is career development, with no statistical difference between women and men. A similar result for gender in career development can also be found in the study of De Hauw and De Vos (2010) although this may be due to work-family conflict (Wang \& Cho, 2013). However, in other cases, women have higher pre-employment expectations than men.

In addition to above-mentioned, similarities between countries were identified, particularly for the dimensions job content, organisational policies and rewards. Possible explanation may be that Slovakia and the Czech Republic were one country for many decades, they shared the majority of their history and their cultures are still inseparable (Štěpánková et al., 2020). This determines partially the values, attitudes, and 
beliefs of the members of each generation. In addition to this, our study also suggests that Slovaks have higher expectations related to career development and social atmosphere than Czechs. Kolman et al. (2003) found in their study that Slovakia is more collectivistic country while the Czech Republic is more individualistic. This would lead to the fact that members of collectivist culture tend to focus more on social cohesion, nice workplace atmosphere and pleasant colleagues to compare with members of individualistic culture.

In summary, these findings lead to the conclusion that some characteristics (e.g. geographical environment, professional experience, national culture, gender) may shape employment expectations more than generational differences. As such, we tend to agree with Guillot-Soulez and Soulez (2014) and Maloni et al. (2019) that different characteristics within a single generational cohort may better explain individuals' expectations than their belonging to a generational cohort. In other words, based on our results, both generations place slightly more emphasis on rewards and organisational policies. On the contrary, they perceive the importance of social atmosphere in the workplace differently. Nevertheless, members of each generation may have particular preferences that do not correspond in some cases with the reported stereotypes of their cohort. Therefore, we recommend focusing more on the individual characteristics or values of the entering generation of employees than their general differences from Generation Y, which is currently the majority among employees.

The results of the study have practical implications. A better understanding of workplace expectations of both generations enables organisations to design effective recruitment and retention strategies for future and current employees. Next, the management of companies must regularly identify the satisfaction and requirements of each generation as their customers (Suchánek \& Králová, 2018). Finally, instead of treating current or potential employees simply as members of one generation, HR managers should appreciate heterogeneity within generations, including gender and national diversity. Moreover, the study has fostered a more precise understanding of the emerging Generation Z.

\section{Limitations and Future Research}

The present research has certain limitations. First, this study proceeds from a cohort-based perspective solely viewing generations as collections of people born in a given period, rather than examining the generations as interrelated and multidimensional social groups. Thus, future research should move beyond the cohort perspective and focus on social force perspective. Second, quantitative research based on quota sampling was adopted in the present study. Due to non-probability sampling, the calculated estimates may be slightly biased. To investigate whether generational differences exist and what is their nature, qualitative methods should be included in future research. Third, other characteristics than those we used in the present study should also be examined to reveal further differences and similarities across generations. Finally, the extension of the study to the Visegrad Four countries could also be considered.

Acknowledgements: This paper was supported by the Grant No. SGS-2020-015 "Research in selected areas of management and marketing of organisations in the context of demographic and technological changes", and by the Grant No. 18-01159S "Organisations success related to professional education: identifying key factors" of the Czech Science Foundation (GAČR).

\section{References}

Baldonado, A. M. (2018). Leadership and The Gen Z: Motivating the Gen Z Workers and Their Impact to the Future. International Journal of Managerial Studies and Research (IJMSR), $6(1)$, 56-60. https://doi.org/10.20431/23490349.0601008

Bejtkovský, J. (2016). The Employees of Baby Boomers Generation, Generation X, Generation $Y$ and Generation $Z$ in Selected Czech Corporations as Conceivers of Development and Competitiveness in their Corporation. Journal of Competitiveness, 8(4), 105-123. https://doi.org/10.7441/joc.2016.04.07

Bencsik, A., Juhász, T., \& Horváth-Csikós, G. (2016). Y and Z Generations at Workplaces. Journal of Competitiveness, 6(3), 90-106. https://doi.org/10.7441/joc.2016.03.06

Brosdahl, D. J. C., \& Carpenter, J. M. (2011). Shopping orientations of US males: A generational cohort comparison. Journal of 
Retailing and Consumer Services, 18(6), 548-554. https://doi.org/10.1016/j.jretconser.2011.07.005

Campbell, W. K., Campbell, S. M., Siedor, L. E., \& Twenge, J. M. (2015). Generational differences are real and useful. Industrial and Organizational Psychology: Perspectives on Science and Practice, 8(3), 324-331. https://doi.org/10.1017/iop.2015.43

Carpenter, J. (2012). Researchers of tomorrow: The research behaviour of Generation $Y$ doctoral students. Information Services and Use, 32(1-2), 3-17. https://doi. org/10.3233/ISU-2012-0637

Costanza, D. P., \& Finkelstein, L. M. (2015). Generationally Based Differences in the Workplace: Is There a There There? Industrial and Organizational Psychology: Perspectives on Science and Practice, 8(3), 308-323. https:// doi.org/10.1017/iop.2015.15

Cseh-Papp, I., Varga, E., Szabó, K., Szira, Z., \& Hajós, L. (2017). The appearance of a new generation on the labour market. International Journal of Engineering Tome, 15(1), 123-130.

CVVM. (2019). How does the public opinion research centre select respondents? Retrieved April 14, 2020, from https://cvvm.soc. cas.cz/en/cvvm2/frequently-asked-questionsmenu/4847-how-does-the-public-opinionresearch-centre-select-respondents

De Hauw, S., \& De Vos, A. J. (2010). Millennials' Career Perspective and Psychological Contract Expectations: Does the Recession Lead to Lowered Expectations? Journal of Business and Psychology, 25(2), 293-302. https://doi. org/10.1007/s10869-010-9162-9

De Vos, A., De Stobbeleir, K., \& Meganck, A. (2009). The Relationship Between Career-Related Antecedents and Graduates' Anticipatory Psychological Contracts. Journal of Business and Psychology, 24(3), 289-298. https://doi.org/10.1007/s10869-009-9107-3

Deloitte. (2018). Welcome to Generation Z. Retrieved May 13, 2020, from https:// www2.deloitte.com/content/dam/Deloitte/us/ Documents/consumer-business/welcome-togen-z.pdf

Dencker, J. C., Joshi, A., \& Martocchio, J. J. (2008). Towards a theoretical framework linking generational memories to workplace attitudes and behaviors. Human Resource Management Review, 18(3), 180-187. https:// doi.org/10.1016/j.hrmr.2008.07.007

Dou, J., \& Li, S. (2013). The succession process in Chinese family firms: A guanxi perspective. Asia Pacific Journal of Management, 30(3), 893-917. https://doi.org/10.1007/s10490012-9287-7

Eger, L., \& Egerová, D. (2013). e-Learning trends in Central Europe: The case of the Czech Republic. Knowledge Management \& E-Learning, 5(3), 375-387. https://doi. org/10.34105/j.kmel.2013.05.027

Eger, L., Klement, M., Tomczyk, L., Pisoňová, M., \& Petrová, G. (2018). Different user groups of University students and their ICT competence: Evidence from three countries in Central Europe. Journal of Baltic Science Education, 17(5), 851-866. https://doi. org/10.33225/jbse/18.17.851

Eurostat. (2020). Digital economy and society statistics - households and individuals. Retrieved April 14, 2021, from https://ec.europa. eu/eurostat/statistics-explained/index.php/ Digital_economy_and_society_statistics_-_ households_and_individuals

Fernandes, T., Sunkarapalli, G., Nandinee, D., \& Pallavi, V. (2016). Optimism and psychological contract on life effectiveness and work effort in IT employees. Indian Journal of Positive Psychology, 7(4), 423-428. https://doi. org/10.15614/ijpp\%2F2016\%2Fv7i4\%2F133875

Fratričová, J., \& Kirchmayer, Z. (2018). Barriers to work motivation of Generation Z. Journal of Human Resource Management, 21(2), 28-39.

Freese, C., \& Schalk, R. (2008). How to Measure the Psychological Contract? A Critical Criteria-Based Review of Measures. South African Journal of Psychology, 38(2), 269-286. https://doi.org/10.1177/008124630803800202

Freese, C., Schalk, R., \& Croon, M. (2011). The impact of organizational changes on psychological contracts. Personnel Review, 40(4), 404-422. https://doi.org/10.1108/00483481111133318

Glass, A. (2007). Understanding generational differences for competitive success. Industrial and Commercial Training, 39(2), 98-103. https://doi.org/10.1108/00197850710732424

Goh, E., \& Lee, C. (2018). A workforce to be reckoned with: The emerging pivotal Generation $Z$ hospitality workforce. International Journal of Hospitality Management, 73, 20-28. https://doi. org/10.1016/j.jhm.2018.01.016

Gresse, W., Linde, B., \& Schalk, R. (2013). Sense of deservingness: What are the entitlement beliefs of students in their anticipatory psychological contract? Management Review, 24(4), 270-288. https://doi.org/10.5771/0935-9915-2013-4-269 
Guillot-Soulez, C., \& Soulez, S. (2014). On the heterogeneity of Generation $Y$ job preferences. Employee Relations, 36(4), 319332. https://doi.org/10.1108/ER-07-2013-0073

Hays, R. D., Liu, H., \& Kapteyn, A. (2015). Use of Internet panels to conduct surveys. Behavior Research Methods, 47(3), 685-690. https://doi.org/10.3758/s13428-015-0617-9

Hothorn, T., Bretz, F., \& Westfall, P. (2008). Simultaneous inference in general parametric models. Biometrical Journal: Journal of Mathematical Methods in Biosciences, 50(3), 346-363. https://doi.org/10.1002/bimj.200810425

Howe, N., \& Strauss, W. (2000). Millennials Rising: The Next Generations. New York, NY: Vintage Books.

Ignatius, J. S., \& Hechanova, M. R. M. (2014). Internet usage from a generational perspective. Philippine Journal of Psychology, 47(1), 133-152.

Issa, T., \& Isaias, P. (2016). Internet factors influencing generations $Y$ and $Z$ in Australia and Portugal: A practical study. Information, Processing \& Management, 52(4), 592-617. https://doi.org/10.1016/j.ipm.2015.12.006

Jones, J. S., Murray, S. R., \& Tapp, S. R. (2018). Generational Differences in the Workplace. The Journal of Business Diversity, 18(2), 88-97. https://doi.org/10.33423/jbd. v18i2.528

Knapp, C. A., Weber, C., \& Moellenkamp, S. (2017). Challenges and strategies for incorporating Generation Z into the workplace. Corporate Real Estate Journal, 7(2), 137-148.

Kolman, L., Noorderhaven, N. G., Hofstede, G., \& Dienes, E. (2003). Cross-cultural differences in Central Europe. Journal of Managerial Psychology, 18(1), 76-88. https:// doi.org/10.1108/02683940310459600

Kubátová, J. (2016). Work-Related Attitudes of Czech Generation Z: International Comparison. Central European Business Review, 5(4), 61-70. https://doi.org/10.18267/j.cebr.167

Kutlák, J. (2018). Vícegenerační řízení na pracovišti: Vliv na personální procesy [Multigeneerational Management in the Workplace: Impact on Human Resources Processes]. Trendy $v$ podnikání [Business Trends], 8(4), 84-95. https://doi.org/10.24132/ jbt.2018.8.4.84_95

Kutlák, J. (2019). Generations $Y$ and $\mathrm{Z}$ in the Workplace: Perception of Teamwork. ACC JOURNAL, 25(2), 65-77. https://doi. org/10.15240/tul/004/2019-2-005
Lancaster, L. C., \& Stillman, D. (2010). The M-factor: How the Millennial Generation Is Rocking the Workplace. New York, NY: Harper Business.

Lanier, K. (2017). 5 things HR professionals need to know about Generation Z: thought leaders share their views on the HR profession and its direction for the future. Strategic HR Review, 16(6), 288-290. https://doi. org/10.1108/SHR-08-2017-0051

Lester, S. W., Standifer, R. L., Schultz, N. J., \& Windsor, J. M. (2012). Actual Versus Perceived Generational Differences at Work: An Empirical Examination. Journal of Leadership \& Organizational Studies, 19(3), 341-354. https:// doi.org/10.1177/1548051812442747

Lim, P., \& Parker, A. (2020). Mentoring Millennials in an Asian Context: Talent Management Insights from Singapore. Bingley: Emerald Publishing Limited. https://doi. org/10.1108/9781789734836

Lub, X. D., Bijvank, N., Bal, P. M., Blomme, R., \& Schalk, R. (2012). Different or alike? Exploring the psychological contract and commitment of differentgenerations of hospitality workers. International Journal of Contemporary Hospitality Management, 24(4), 553-573. https://doi.org/10.1108/09596111211226824

Lub, X. D., Bal, P. M., Blomme, R. J., \& Schalk, R. (2016). One job, one deal... or not: do generations respond differently to psychological contract fulfillment? The International Journal of Human Resource Management, 27(6), 653-680. https://doi.org/1 $0.1080 / 09585192.2015 .1035304$

Lyons, S., \& Kuron, L. (2014). Generational differences in the workplace: A review of the evidence and directions for future research. Journal of Organizational Behavior, 35(S1), 139-157. https://doi.org/10.1002/job.1913

Maloni, M., Hiatt, M. S., \& Campbell, S. (2019). Understanding the work values of Gen $Z$ business students. The International Journal of Management Education, 17(3), 1-13. https://doi.org/10.1016/j.ijme.2019.100320

ManpowerGroup. (2016). Miléniálové a Kariéra: Vize 2020 [Millennials and Careers: Vision 2020]. Retrieved May 15, 2020, from https://manpower.cz/media/milenialove.pdf

Mencl, J., \& Lester, S. W. (2014). More Alike Than Different: What Generations Value and How the Values Affect Employee Workplace Perceptions. Journal of Leadership \& Organizational Studies, 21(3), 257-272. https://doi.org/10.1177/1548051814529825 
Meret, C., Fioravanti, S., lannotta, M., \& Gatti, M. (2018). The Digital Employee Experience: Discovering Generation Z. In C. Rossignoli, F. Virili, \& S. Za (Eds.), Digital Technology and Organizational Change: Reshaping Technology, People, and Organizations Towards a Global Society (Vol. 23, pp. 241-256). Cham: Springer. https://doi.org/10.1007/978-3-319-62051-0_20

Miller, J. (2018). A 16-Year-Old Explains 10 Things You Need to Know About Generation Z. Retrieved May 15, 2020, from https://www. shrm.org/hr-today/news/hr-magazine/1118/ pages/a-16-year-old-explains-10-things-youneed-to-know-about-generation-z.aspx

Moore, S., Grunberg, L., \& Krause, A. J. (2015). Generational Differences in Workplace Expectations: A Comparison of Production and Professional Workers. Current Psychology, 34(2), 346-362. https://doi.org/10.1007/s12144-014-9261-2

Noble, S. M., \& Schewe, C. D. (2003). Cohort segmentation: An exploration of its validity. Journal of Business Research, 56(12), 979-987. https://doi.org/10.1016/S0148-2963(02)00268-0

Ochoa, C., \& Porcar, J. M. (2018). Modeling the effect of quota sampling on online fieldwork efficiency:An analysis of the connection between uncertainty and sample usage. International Journal of Market Research, 60(5), 484-501. https://doi.org/10.1177/1470785318779545

Parry, E., \& Urwin, P. (2011). Generational Differences in Work Values: A Review of Theory and Evidence. International Journal of Management Reviews, 13(1), 79-96. https:// doi.org/10.1111/j.1468-2370.2010.00285.x

Puiu, S. (2017). Generation Z - An educational and managerial perspective. Young Economists Journal/Revista Tinerilor Economisti, 14(29), 61-72.

$\mathrm{R}$ Core Team. (2020). R: A language and environment for statistical computing. Vienna: $\mathrm{R}$ Foundation for Statistical Computing. Retrieved February 29, 2020, from https://www.R-project.org

Rodriguez, M., Boyer, S., Fleming, D., \& Cohen, S. (2019). Managing the Next Generation of Sales, Gen Z/Millennial Cusp: An Exploration of Grit, Entrepreneurship, and Loyalty. Journal of Business-to-Business Marketing, 26(1), 43-55. https://doi.org/10.108 0/1051712X.2019.1565136

Rood, A. S. (2011). Understanding Generational Diversity in the Workplace: What Resorts Can and are Doing. Journal of Tourism Insights, 1(1), 80-88. https://doi. org/10.9707/2328-0824.1009
Ruchika, P., \& Prasad, A. (2019). Untapped Relationship between Employer Branding, Anticipatory Psychological Contract and Intent to Join. Global Business Review, 20(1), 194-213. https://doi.org/10.1177/0972150917713897

Schewe, C. D., \& Meredith, G. (2004). Segmenting global markets by generational cohorts: determining motivations by age. Journal of Consumer Behaviour, 4(1), 51-63. https://doi.org/10.1002/cb.157

Schroth, H. (2019). Are You Ready for Gen $Z$ in the Workplace? California Management Review, 61(3), 1-14. https://doi. org/10.1177/0008125619841006

Smola, K. W., \& Sutton, C. D. (2002). Generational Differences: Revisiting Generational Work Values for the New Millennium. Journal of Organizational Behavior, 23(4), 363-382. https://doi.org/10.1002/job.147

Sobrino-De Toro, I., Labrador-Fernández, J., \& De Nicolás, V. L. (2019). Generational Diversity in the Workplace: Psychological Empowerment and Flexibility in Spanish Companies. Frontiers in Psychology, 10, 1-11. https://doi.org/10.3389/fpsyg.2019.01953

Suchánek, P., \& Králová, M. (2018). Customer satisfaction and different evaluation of it by companies. Economic Research - Ekonomska Istraživanja, 31(1), 1330-1350. https://doi.org/10.1080/133167 7X.2018.1484786

Sutton, G., \& Griffin, M. A. (2004). Integrating expectations, experiences, and psychological contract violations: A longitudinal study of new professionals. Journal of Occupational and Organizational Psychology, 77(4), 493-514. https://doi.org/10.1348/0963179042596487

Šimsová, J., \& Reissová, A. (2016). How much will I earn? Expectations versus reality. E\&M Economics and Management, 19(2), 4-20. https://doi.org/10.15240/tul/001/2016-2-001

Štěpánková, L., Kadlčíková, D., \& Scherman, A. Z. (2020). Czech and Slovak life scripts: the rare case of two countries that used to be one. Memory, 28(10), 1204-1218. https:// doi.org/10.1080/09658211.2020.1828476

Talk Online Panel. (2019). Panelbook. Retrieved April 14, 2021, from http:// talkonlinepanel.net/panelbook

Tang, F. (2019). A critical review of research on the work-related attitudes of Generation $Z$ in China. Social Psychology and Society, 10(2), 19-28. https://doi.org/10.17759/ sps. 2019100203 
Tapscott, D. (2009). Grown Up Digital: How the Net Generation is Changing Your World. New York, NY: McGraw-Hill.

Twenge, J. M., Campbell, S. M., Hoffman, B. J., \& Lance, C. E. (2010). Generational differences in work values: Leisure and extrinsic values increasing, social and intrinsic values decreasing. Journal of Management, 36(5), 1117-1142. https://doi. org/10.1177/0149206309352246

Wang, W., \& Cho, T. (2013). Work-Family Conflict Influences on Female's Career Development through Career Expectation. Journal of Human Resource and Sustainability Studies, 1(3), 43-50. https://doi.org/10.4236/ jhrss.2013.13007
Werth, E. P., \& Werth, L. (2011). Effective Training for Millennial Students. Adult Learning, 22(3), 12-19. https://doi. org/10.1177/104515951102200302

Wiedmer, T. (2015). Generations do differ: Best practices in leading traditionalists, boomers, and generations $\mathrm{X}, \mathrm{Y}$, and Z. Delta Kappa Gamma Bulletin, 82(1), 51-58.

Zúñiga, D. C., Garcia, D. A., Barroso, J. R., \& Calvo, J. M. D. M. (2019). Work Ethic: Analysis of differences between four generational cohorts. Anales De Psicología, 35(3), 496-505. https://doi.org/10.6018/analesps.35.3.342671 